\title{
Development of a recombinant protein based ELISA for the diagnosis of canine leptospirosis
}

\author{
Wallace Pereira ${ }^{1 *}$, André Alex Grassmann ${ }^{1}$, Micaela Domingues ${ }^{1}$, Flávia McBride², Alan McBride ${ }^{1}$ \\ From 5th Congress of the Brazilian Biotechnology Society (SBBIOTEC) \\ Florianópolis, Brazil. 10-14 November 2013
}

\begin{abstract}
Background
Leptospirosis is an emergent zoonotic disease caused by pathogenic Leptospira spp., and humans are regarded as an accidental or dead-end host [1]. The global incidence of severe human leptospirosis was estimated to be approximately 500.000 cases worldwide, although this is likely an underestimate due to the lack of a reliable diagnostic test. Mortality ranges from 10 to $>50 \%$ for Weil's disease or severe pulmonary hemorrhage syndrome (SPHS), respectively [2]. The microscopic agglutination test (MAT) is the standard test for this disease, however, it requires paired serum samples, is laborious, difficult to analyze and subjective [3]. Apart from the danger connected with rodents, which are the main vectors of leptospires, occurrence of the disease in dogs can generate a higher risk of infection for humans. Thus, a novel sensitive and specific serological test providing a rapid and secure diagnosis is urgently required for the laboratorial diagnosis of leptospirosis. In this study, 15 recombinant proteins from $L$. interrogans were expressed, purified and evaluated in an indirect ELISA using canine sera that were characterized by the MAT and a whole-cell Leptospira ELISA.
\end{abstract}

\section{Methods}

Fifteen recombinant polypeptides based on LigB, LigA LipL32, LemA, OmpL37, FlaA1 and FlaB1 were cloned and expressed in Escherichia coli, purified by $\mathrm{Ni}^{2+}$ affinity chromatography, quantified and stored at $-20^{\circ} \mathrm{C}$ until use. The recombinant proteins were assessed in a checkerboard ELISA to evaluate their capability discriminate between infected and non-infected canine sera, and to determine the optimal combinations of antigen, canine sera and anti-dog IgG and IgM HRP conjugate antibodies. After the initial screening, two recombinant proteins were

${ }^{1}$ Núcleo de Biotecnologia, CDTec, Universidade Federal de Pelotas, Pelotas, Brazil

Full list of author information is available at the end of the article selected and tested against a serum panel, 10 positive and 10 negative serum samples.

\section{Results and conclusions}

Following the preliminary screening using pooled sera, rLigBrep and rLipL32 were evaluated using a panel of individual canine serum samples. The optimal concentrations of antigen for the coating step was $100 \mathrm{ng} /$ well. The optimal sera dilution was 1:200 for rLigBrep, 1:100 for rLipL32, 1:2500 for the IgG and 1:5000 for the IgM conjugates. Based on the negative sera, the average OD for rLigBrep was $0.24 \pm 0.11$ for the negative pool and the cut-off was calculated as OD $=0.47 .100 \%$ of the negative sera were negative and $70 \%$ of the characterized positive were identified as positive under these conditions. The average OD based on rLipL32 was $0.2 \pm 0.08$ for the negative pool, equivalent to a cut-off of OD = $0.36 .100 \%$ of negative sera were negative and $50 \%$ positive sera were identified as positive. The anti-dog-IgG conjugate exhibited the best specificity and sensitivity. The recombinant protein rLigBrep demonstrated potential as a diagnostic tool for canine leptospirosis, 70.0\% sensitivity and $100 \%$ specificity. The native protein, $\mathrm{LigB}$, is highly conserved in pathogenic Leptospira spp. and therefore represents an ideal candidate for further studies.

\section{Authors' details}

'Núcleo de Biotecnologia, CDTec, Universidade Federal de Pelotas, Pelotas, Brazil. ${ }^{2}$ Medicina, Universidade Católica de Pelotas, Pelotas, Brazil.

Published: 1 October 2014

\section{References}

1. Adler B, de la Pena Moctezuma A: Leptospira and leptospirosis. Veterinary Microbiology 2010, 140(3-4):287-296.

2. Mcbride AJ, Athanazio DA, Reis MG, Ko Al: Leptospirosis. Curr Opin Infect Dis 2005, 18(5):376-86. 
3. WHO e ILS: Human leptospirosis: guidance for diagnosis, surveillance and control. Malta: World Health Organization 2003.

doi:10.1186/1753-6561-8-S4-P139

Cite this article as: Pereira et al: Development of a recombinant protein

based ELISA for the diagnosis of canine leptospirosis. BMC Proceedings

2014 8(Suppl 4):P139.

Submit your next manuscript to BioMed Central and take full advantage of:

- Convenient online submission

- Thorough peer review

- No space constraints or color figure charges

- Immediate publication on acceptance

- Inclusion in PubMed, CAS, Scopus and Google Scholar

- Research which is freely available for redistribution

Submit your manuscript at 